\title{
慢性膵炎の手術成績と予後を左右する因子の検討
}

\author{
東北大学第 1 外科教室 \\ 能登浾。斉藤 洋一宮下 英士 \\ 狩野研次郎佐藤 寿雄

\section{LONG TERM FOLLOW-UP STUDY AND PROGNOSTIC FACTORS AFTER SURGERY FOR CHRONIC PANCREATITIS} \\ Noboru NOTO, Yoichi SAITO, Eishi MIYASHITA, Kenjiro KANO and Toshio SATO \\ Department of Surgery, Tohoku University, School of Medicine, Sendai
}

索引用語 : 慢性膵炎, 遠隔成績, 術後膵機能, 蒯管空䐎側々吻合術, 予後を左右する因子

はじめに

自験例94例の手術成績を遠隔時の病態を中心に検討を 加克，外科的予後を左右する因子を術前における臨床像 との関連から明らかにするとともに，慢性膵炎の手術適 応，術式選択および手術の時期について著者らの見解を 述べながら若干の文献的考察を加えたい．

\section{I. 教室例の概要}

1960年以降1979年 2 月 までの慢性膵炎手術例 は94例 で, 男68例，女 26 例，年齢は11歳から72歳まで，平均 44 藏である. 成因は, アルニール性のものが39例と最も多 <, 胆石症 12 例, 膆外傷 5 例, 急性膵炎 4 例であり, 残 る34例は不明 (特発性) である. PS 試験では84例中70 例が障害されており，50g OGTT では85例中46例が糖 疗病型を示している。

疼痛は全例にみられ，激・疝痛あるい:持続性のむの が69例 $(73 \%)$ であり，榺石は59例 $(63 \%)$ 亿, 襄胞は 23 例 $(24 \%)$ ，膵膿瑝は 1 例に，膵癌は 4 例に合併し ていた．胆管狭窄や胆道疾患を伴うものは26例（28\%） である.

\section{II. 検索成績}

\section{1. 手術々式}

94例に対し99回の手術を行っているが，表 1 に示すよ

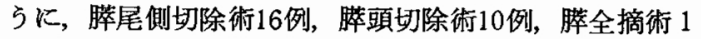
例と膆管减圧手術としては膵管空腸側々吻合術 38 例, 乳

* 第13回日消外総会シンポ吕 慢性膵炎の外科治療
表 1 僈性萃炎に対する手術術式之直接成績 (東北大一外, 79.2)

\begin{tabular}{|c|c|c|c|}
\hline & 1 & 吉死的 & 死 因 \\
\hline 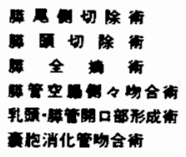 & $\begin{array}{c}16^{* *} \\
10 \\
1 \\
38^{*} \\
7 \\
4\end{array}$ & $\begin{array}{l}1^{*} \\
1 \\
1\end{array}$ & 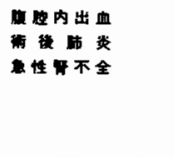 \\
\hline 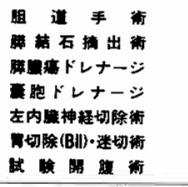 & $\begin{array}{c}13 \\
3 \\
1 \\
1 \\
1 * \\
1^{*} \\
3\end{array}$ & 3 & 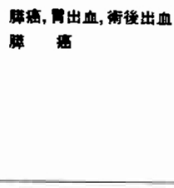 \\
\hline H & 99 & 7 & \\
\hline
\end{tabular}

頭・膵管開口部形成術 7 例である. 膵虽胞・消化管吻合 術 4 例, 胆道系に対する手術は13例で, その他, 膵管内 に1〜2 この小結石のあるもので経実質的に結石のみ摘 出したるのや膵膿湯, 霍胞のドレナージに止めたものな どである.

2. 術後合併症之直接成績

術後合併症は, 脺瘦形成 9 例, 腹腔内膿瘍 7 例, 晹閉 塞 6 例, 消化管出血 5 例, 腹腔内出血 2 例などである.

膵瘦 9 例のうち 2 例は難治性膵瘦となったが，他の 7 例 は自然閉塞して退院した. 合併症で再開腹したものは腸 閉塞 2 例, 消化管出血 1 例など計 5 例である.

直接死亡は7 例 $(7.4 \%)$ で，死因は術後合併症によ るものは, 腹腔内出血 2 例, 肺炎, 急性腎不全, 急性胃

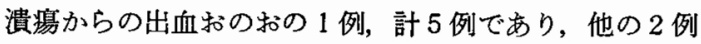


表 2 疼痛に対する效果

\begin{tabular}{|c|c|c|c|c|}
\hline 式 & 例数 & 消失 & 軽快 & 不変 \\
\hline 膵 頭 切 除 術 & 9 & $6(67)$ & 2 & 1 \\
\hline 膰 尾 側 切 除 術 & 14 & $11(79)$ & 3 & \\
\hline 勝管空腸例々吻合術 & 38 & $26(68)$ & 8 & $4(11)$ \\
\hline 胆道 手 術 & 10 & 8 & 2 & \\
\hline 乳頭・膵管開口部形成術 & 6 & 1 & 4 & 1 \\
\hline 臌胞消化管吻合術 & 2 & 1 & 1 & \\
\hline 膵 結 石 摘 出術 & 1 & & 1 & \\
\hline 左内臓神 経切除術 & 1 & 1 & & \\
\hline 胃切除 (B- II) - 迷切術 & 1 & 1 & & \\
\hline 計 & 82 & $55(67)$ & $21(26)$ & $6(7)$ \\
\hline
\end{tabular}

は術前から合併していた脺癌によるものである.

3. 疼痛に対する効果

耐術者のうち, 試験開腹術と術後 6 力月以内の 5 例を 除く 82 例の疼痛に対する効果は表 2 の上 5 に, 消失 55 例 $(67 \%)$, 軽快21例 $(26 \%)$, 不変6例 (7\%) である. 疼痛消失例出, 胆道手術で 10 例中 8 例と最も高率であ り，脺尾側切除術では $79 \%$, 脺管空腸吻合術 $68 \%$, 脺頭 切除術では67\%であるのに対し，乳頭・膵管開口部形成 術 6 例では消失したもの 1 例である. 疼痛不変の 6 例の らち, 膵頭切除術の 1 例は脺癌再発によるものであり, 脺管空腸吻合術の 4 例は全て脺石例で，らち 3 例は若年 者の特発性䅈炎である.膵管開口部形成術の 1 例は周囲 との瘾着が高度で，しかも膵管の状態を確認できないま ま本術式を行ったものである.な拉，疼痛残存のため再 手術を行ったものが 5 例あるが，上記の成續は再手術後 のものである.

4. 膆内外分泌機能（図 1，2）

PS 試験による膵外分泌機能の成績を術前と遠隔時と で比較してみると，胆道手術や膵尾側切除術などの11例 では遠隔時に改善されたもの 4 例，不変 5 例，悪化 2 例 であり，膵管空腸吻合術 の11例ではそれぞれ 1 例， 6 例， 4 例である.

また，脂肪の消化吸収試験では，遠隔時に䔬便中脂肪 排泄量が5g 以上の障害例は34例中29例であり, 術前に 比べて明らかに減少しているのは19例のうち 2 例のみで ある.

PFD テストでは，遠隔時の成績であるが，33例中29 例が正常範囲以下の值を示している.

膵内分泌機能の変動を50g OGTT の成績で比較して
図 1 膵外分泌機能検査

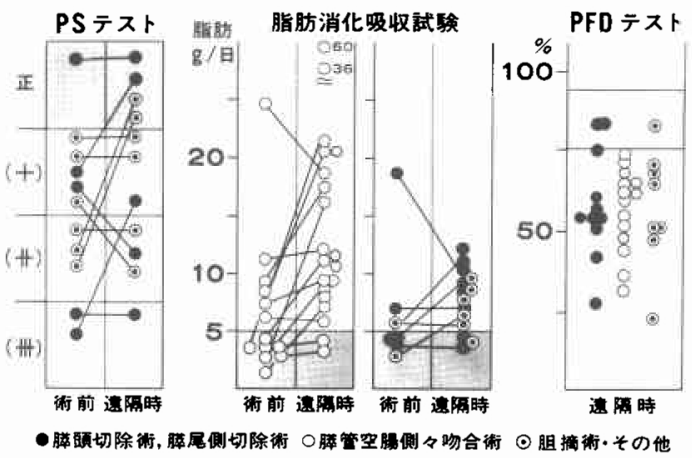

図 2 膵内分泌機能検查 (50g OGTT)

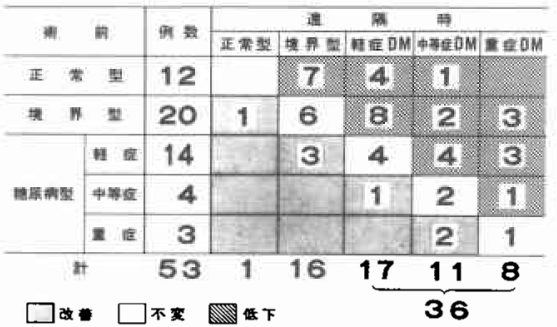

みると, 術後平均 3 年 5 力月経過で, 53 例のうち遠隔時 に改善されたもの 7 例 $(13 \%)$, 不変13例 $(25 \%)$, 低下 33例（62\%）である. 術前が正常または境界型であった 32例のうら遠隔時に糖疗病型となったものは18例で治療 を要する中等症以上のものが 6 例である. 逆に術前糖尿 病型であった21例で遠隔時に正常または境界型と改善さ れたものは 3 例である. 術式別にみると, 膵切除術15例 では改善例はなく, 脺尾側切除術 8 例中 7 例が低下して 扣り, 膵管空腸吻合術29例では改善 4 例 $(14 \%)$, 不変 5 例，低下20例（69\%）である.

\section{5. 体重の変動}

69例飞ついて遠隔時の体重を術前と比較してみると， 術前体重の $5 \%$ 以上の增加例 21 例 (30\%), 減少例20例 (29\%) で, 残る28例 (41\%) は，5\%以内の増減（不 変)飞止末っている. 膵頭切除術の 8 例では 5 例が減少 しているのに対し，膵管空腸吻合術の32例では25例（79 \%）が不変ないし増加である.

\section{6. 社会復帰状況}

現在生存中の69例の就業状況をみると, 術前と同じ仕 事に従事しているものは48例 (69\%), 軽労働に 变卉た もの11例 $(16 \%)$, 休業中のむの10例 $(14 \%)$ であるが 
休業中のもののうち疼痛や糖尿病の悪化など身体的理由 によるるのは 5 例である. したがって，64例（93\%）は 社会復帰していることになる. 各術式別での差はみられ ない.

7. 遠隔時死亡例と死因

遠隔死亡は13例である. 死因は糖尿病またはその合併 症が 7 例と最も多く, 肝疾患 2 例, 他臟器癌 2 例, 肺結 核，膵癌再発和のおの 1 例である（表 3)．脺管空腸吻 合術の 8 例中 6 例は糖尿病の合併症によるものである が，いずれるフルコール性膵炎であり，術後す禁酒しな かったものである.

表 3 術式別遠隔成績

\begin{tabular}{|c|c|c|c|c|c|c|}
\hline in: & 解 & 昷 $\mathrm{s}$ & pont & $\pi=$ & E.工 & 此甶 \\
\hline a 5 दो 4 का & 9 & (56) & 1 & 1 & 2 & If \\
\hline 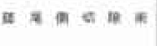 & 14 & (64) & 2 & 1 & 2 & 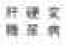 \\
\hline แ & 38 & $\begin{array}{l}19 \\
(50)\end{array}$ & 7 & 4 & e & 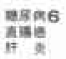 \\
\hline 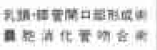 & $\begin{array}{l}6 \\
2\end{array}$ & $\begin{array}{l}1 \\
1\end{array}$ & 4 & 1 & & \\
\hline E $\quad$ 而 & 10 & (8) & 1 & & 1 & Fition a \\
\hline 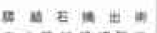 & 1 & & 1 & & & \\
\hline 在 开 & 1 & 1 & & & & \\
\hline 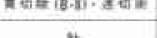 & 9? & 1 & & & & \\
\hline it & 62 & 45 & $\begin{array}{l}17 \\
21\end{array}$ & (9) & (16) & \\
\hline
\end{tabular}

\section{8. 遠隔成績}

以上の成績を総合的に判定し手術例の遠隔成績をみる と表 3 の如くである.すすねち，疼痛が消失〜明らかに 軽快し，原職に復帰しているものを“良好”とすると45 例 $(55 \%)$ ，疼痛は軽快しているがな拈治療を必要とし ているもの，および身体的理由で軽労働に変えたものを “やや良好”之すると17例 (21\%)，疼痛不变例，重篤 な合併症で入院をくりかえしているものや就業できない でいるやのを“不良”とすると 7 例 (9\%)，遠隔死亡 13例（16\%）となる．良好例は胆道手術で最も高率であ り，膵切除術と膵管空腸吻合術では有意差はない。

9. 予後を左右する因子

予後と衍前の臨床的事項との関連について検討してみ ると図3のように，まず成因別ではアルコール性膵炎で 良好 $43 \%$ ，やや良好 $26 \%$ ，不良～死亡 $31 \%$ と最も成績が

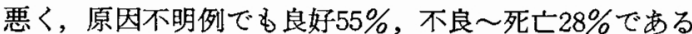
のに対し，胆道原性膵炎や膵外傷・急性膵炎によるるの では良好例がそれぞれ73\%，86\%である，生存曲線をみ ても図4のように, アルュール性膵资の 5 年生存摔は 67 $\% ， 10$ 年生存率は $44 \%$ と他と比べて明らかに成績不良で
図 3 臨床像と予後
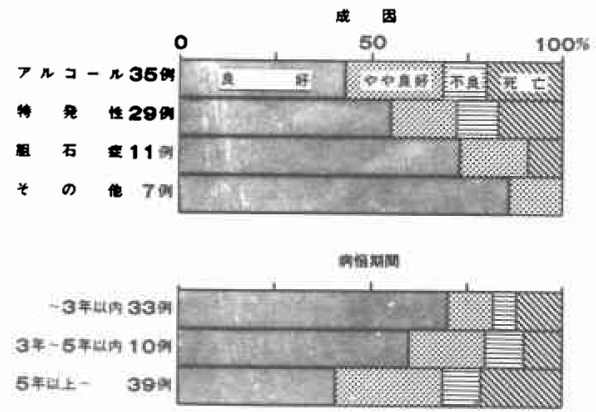

昰表石
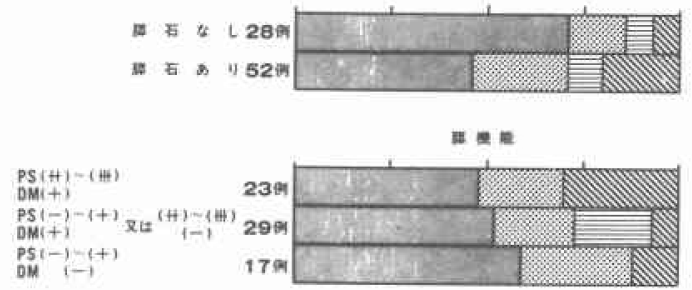

図 4 成因別生存曲線

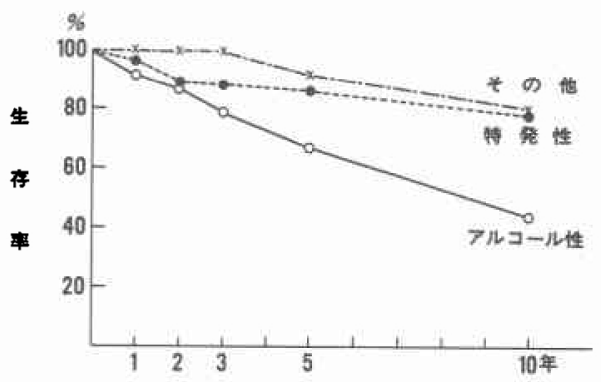

ある.

また，手術までの病悩期間が長いほど予後が悪く，3 年以内のもの々 5 年以上のわのでは良好例がそれぞれ70 \%，41\%と明らかに差がみられる。膵石の有無では，膵

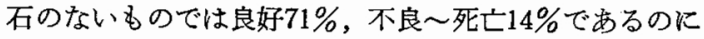
対し，膵石のあるものではそれぞれ $46 \% ， 30 \%$ と明らか に前者で成績が良い。

術前の膆機能障害の程度からみると, PS 試験で中等 度以上の障害で，かつ OGTT が糖疗病型のものでは良 好 $48 \%$, 死亡 $30 \%$ であるのに対し，PS 試験が正常〜軽 度障害で糖尿病型でないものでは，それぞれ $59 \%, 12$ \%であるが，死亡例の死因が前者では慢性膵炎に関連し たものであり, 後者では直腸癌, 肺結核であることを考 慮すれば膵内外分泌機能障害の程度が軽微なほど予後良 
好といえる.

\section{III. 考 察}

最近，慢性膵炎に対する手術症例る增加し，その遠隔 成績の検討から現在では本症に対する手術適応，手術々 式の選択に関してるほぼー定の見解が持たれるようにな った.

すなわち，手術適応についての諸家の報告をみると， いずれも碩固な疼痛をまず第一にあげており，Smith はさらに膵炎の急性発作をくり返えすもの，種々の合併 症すなわち霊胞, 膵㿉, 胆道・十二指腸・門脈の閉塞の みられるもの，癌との鑑別が困難なるのとしている.こ れらの項目の活かに重症糖尿病や消化吸収障害を示すも $の^{2)}$, 上部消化管出血 ${ }^{3)}$ や胆道疾患》の合併例などをも適 応としてあげている. 著者らもたびたび報告(56)》して来 たが，現在では，1）疼痛が著しく内科的治療の無効な もの，2）膵襄胞，膵膿湯，脺瘦を合併するもの，3） 胆道狭窄や胆道疾患を伴うもの，4）膵癌の疑いのある もの，と考えている.

慢性膵炎の手術々式として一般飞行われているるの は，1）膵切除術（膵体尾部切除術，膵頭切除術，95\% 脺尾側切除術，脺全摘術など），2）膵管減圧手術（尾 側滕管空腸吻合術，腈管空腸側々吻合術，乳頭・膵管開 口部形成術など)，3）胆道系に対する手術，4）自律 神経系に対する手術 (内臓神経切除術, 膵頭神経丵切断 術）に大別されよう。その他，合併した膵虽胞に対する ドレナージ手術や膵結石摘出術, 胃切除 (B - II ・迷切 術)，膵管結禁術なども行われる場合がある.

これらの種々の手術々式を症例の病態すなわち成因, 膵病変の抎がりと程度, 膵管の拡張の有無などによって 選択するわけである．著者らの術式選択の基準を図 5 に

図 5 慢性膵炎の病型と手術術式

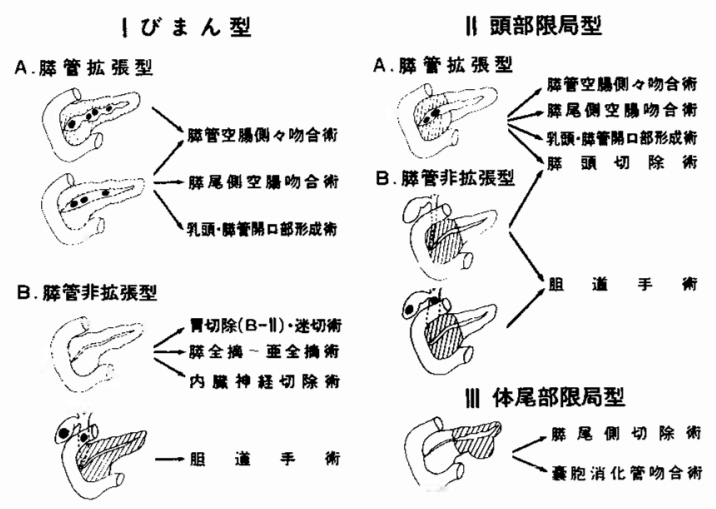

示すが，その詳細 ${ }^{58}$ に2ついてはここでは省略し，2， 3 の事項について考察を加兄る.

膵の部分切除術は膵病変〜主病巣が限局性の場合に適 応となり，脺体尾部切除術の成績はこれまでの報告2)910) をみても教室例においても良好な成績が得られている が，膵頭切除術については積極的に行うものは必ずしす 多くはない. ReMine9" は主病巣が頭部に限局し，臨床 症状が激しい場合を適応としながらも“primary procedure”としてしばしば行うことはなく，脺管の状態を確 認してできるだけ他の術式を選択するという.Guillemin $ら^{11}$ は63例に本術式を行い，術後 3 年の遠隔成績は57例 中15例が死亡し，良好〜やや良好37例（65\%）であり， 6 年 13年経過例 24 例では13例が死亡し，良好〜やや良 好10例であったとし，本術式の有効性を認めながらむ， 他の術式で失敗した脺石合併例に行うべきであると述べ ている.

教室例の膵頭切除術10例についてみると，膵癌合併 1 例, 癌の疑い 3 例, 襄胞内出血 2 例之膵結石を伴万頭部 限局性膆炎 4 例である. 直死例は腸閉塞を併発し再手術 後に肺炎で死亡した 1 例で, 遠隔成績は糖尿病が新たに 3 例発症し，体重減少は 5 例に，吸収不良症候群で加療 を受けたもの 2 例，死亡 2 例であるが，疼痛は 6 例で完 全に消失している. 脺䫓部限局型の 4 例では 1 例が肺結 核で死亡したが，残る 3 例はきうめて良好に経過してい る. 腫瘤や囊胞を形成し, 癌との鑑別が困難なものや十 二指腸に病変が就よんでいるもののほかに，膵石をとも なら高度な病変が膵頭部に限局しているものも本術式の 適応と考えておら，最近さらに2 例に行っている。

また，さらに抎大した荟切除術すなわち $95 \%$ 膵尾側切 除術 ${ }^{2213)}$ や膵全摘術 ${ }^{14)}$ が試みられ，その成績が注目され ている. しかし，これらの膵大量切除術は手術手技上の 問題之脺内外分泌機能の欠落が必発であり合併症や死亡 例も多く，その適応は厳格にとるべきである. 教室例の 脺全摘術 1 例は脺がびまん性に萎縮, 硬化して震胞が多 発し，膵機能が高度に障害されていたものである。

Frey ら $^{13}$ は積極的に膵切除術を取り上げているが， その遠隔成績の検討から 80 ～95\% 尾側切除術では糖尿 病, 脂肪便の出現頻度が高く, 術後合併症や遠隔時死亡 例も多いことから，可能ならば40～ $80 \%$ の切除範围に止 めることをすすめている.

膵管拡張例では膵管減圧手術が適応となる. これは疼 痛の原因となっている膵液のうっ滞を解除し, しかも障 害された膵機能を温存ないし改善させることを目的とす 
るものである.

脺頭側からのドレナージとしては, 十二指腸乳頭笳切

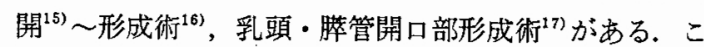
れは乳頭〜膆管開口部近傍に狭窄があり膵管がびまん性 に拡張しているもので適応となるが，欧米の報告をみて も期待したほどの成績はあげられていない，教室例であ 初回手術 7 例のうち疼痛消失例は 1 例の及で 2 例では不 変であり, 実際にはその適応となる症例は少ないむのと 思わ机る。

脺尾側からのドレナージとしては DuVal ${ }^{18)}$ らの尾側 脺空腸吻合術がある.これも膵管の狭窄が1カ所で, び まん性に拡張しているもので適応となる. しかし，進行 した慢性膵炎では多くの場合に膵管の狭窄は多発性であ り，膵管の全長にわたってドレナージする必要がある. すなわち, Puestow ら ${ }^{19}$ によって膆管をその走行に沿っ て大きく切開し空腸と吻合する術式が創案されたが，そ の後多少の改善 $22202{ }^{21}$ が加克られ今日広く応用されてい る. 著者らも膵管扗張例に対しては膵管空腸側々吻合術 を“first choice”として38例に行っている.

脺管がびまん性扗張例では“DuVal 手術”, “Puestow 手術”のどちらも適応となるが, 両術式の遠隔成績を文

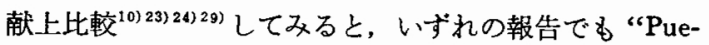
stow 手術”で良い成續が得られて扣り，White ${ }^{25)}$ は十 分な減圧と吻合口の狭窄が起こりにくいことから膵管空 腸側々吻合術を推奖している. Leger $ら^{26)}$ は膵管空腸端 側吻合術を行っているが，遠隔成績を左右する要因の 1 つとして脺管の拡張の程度をあげ, 主膵管が $10 \mathrm{~mm}$ 以上 のものと $5 \mathrm{~mm}$ 以下のものでは良好例がそれぞれ $72 \%$ ， 39\%であったという. そして, 18例の再手術例のうち 9 例で膵管空腸吻合の狭窄がみられ，しかも6 例は膵管が $5 \mathrm{~mm}$ 以下の症例であったといら。

一方, 羽生 ${ }^{27)}$ は膵管空腸吻合術後に胆管狭窄をきた し再手術をした 3 例の経験から, 初回手術時に胆管に少 しでも異常のあるものでは举上した Roux-Y 型空腸の膆 空腸吻合部の肛門側と胆管または胆衰との吻合術を追加 して好結果を得たという。

著者らの38例では術前に黄疸の既往や総胆管の桩張の あったるのは13例であるが，遠隔時に閉塞性黄疸のため に再手術を必要としたものは1例のみである。 Griffin $ら^{4)}$ は42例中 2 例, Leger $ら^{26)}$ は45例中 2 例, Arnesjö $5^{24)}$ は29例中 1 例のみが遠隔時に閉塞性黄疸で再手術を 要したといらょうに, 手術後の黄疸は決して多いもので はない，膵内胆管が高度に狭窄をきたし黄疸がある場合
以外は胆管に多少の異常所見があっても腈管を膵頭部ま で十分に切開し吻合口を大きく作成すれば胆道ドレナー ジは必ずしも追加する必要はないものと著者らは考えて いる.

膵管減圧手術の遠隔時の膵機能の推移については回復 するとするもの ${ }^{1928)}$ と改善は期待でさないとの見解があ る. 教室例の成績は前項で述べたが，PS 試験では膵管 空腸吻合口からの膵液は空腸内にドレナージされるの で，術前の成績と正確には比較できないが，検索しえた 11例のうち改善されたのは 1 例のみであった，消化吸収 試験では脂肪排泄量が術前が $10 \mathrm{~g}$ 以内の 11 例中 6 例は遠 隔時にも $10 \mathrm{~g}$ 以内にとどまっているが(図 1)，全体と しては消化吸収機能は低下する傾向がみられた．内分泌 機能についても耐糖能が改善されたものは前述のように $14 \%$ ，不变 $17 \%$ ，低下 $69 \%$ であった，才なわち，膵内外 分泌機能が 改善されるものは少ないとの結果であった が，体重は80\%の症例で不変〜增加であった，Arnesjö ら ${ }^{24}$ は29例のうち衍後に新たに糖尿病が発症したものは 5 例であったとし，Jordan $5^{23)}$ む膵内外分泌機能は改 善されず, 体重の增加は疼痛の消失によるものであった と述べている.

慢性脺炎の手術成績についてみると，全体としては， Warren $^{30)}$ は79\%に満足すべき成績を得ており，Way $ら^{10)} は 64 \%$, White ${ }^{31)} は 63 \%$, Anderson $5^{32)} は 54 \% に$ 良好な結果を得たとしているのに対し，Griffin ら”はフ ・ルコール性脺资で良好 $35 \%$ ，やや良好 $24 \%$ ，不良 $41 \%$ で あったという。このような差は術後の観察期間や成績判 定の基準も異なることによると思われる. Leger ら ${ }^{26)} の$ 成績を 5 年以上生存したものについてみると, 良好な成 績であったものは縢尾側切除術では68\%，膵頭切除術で $75 \%$ ，膵管空腸吻合術では $48 \%$ ，内臓神経切除術では31 \%であったが，5 年以内の死亡例は膵管空腸吻合術で 7 \%であるのに対し，膵尾側切除術では $42 \%$ ，脺頭切除術 では47\%と高率であったとしている.

手術成績を左右する因子として, ReMine ${ }^{9)}$ は128例 の平均44カ月の経過観察から,フルコール领用者, 胆石 を合併しないもの，脺石のあるもの，脂肪便・糖尿病の あるもの，疼痛が持続性のものでは成績不良であったと いう.アルコール性脺炎とくに術後の领酒の継続を遠隔 成績に影響を与える最も重要なるのとして強調するもの が多く, White ${ }^{25)}$ は非アルコール性膵炎の 9 年生存率 は86\%であるのに対し，アルコール性膵炎では23\%であ ったという，術後禁酒可能かどうかの患者の性格をも術 
式選択の基準の 1 つとし，禁酒できそうもない患者に は膵切除術は避怙，膵管空腸吻合術を行うべきであり， 膵管拡張のない時は拡張するまで手術をできるだけ延期 した方が良いとの報告 ${ }^{26)}$ ある。

教室例での倹索でも上記の内容とほ注同様の結果が得 られている. アルコール性粹炎や病悩期間が長く, 膆石 を合併し, 膵機能が高度に障害されている症例では手術 成續は満足するものでなく, 脺病変が高度なるのでは理 想とする術式を行いえない場合も少なくないしたがっ て, 著者らは疼痛発作が頻回にみられるとか, 膵病変が 限局性のもの，主膵管内に結石があり拡張しているすの では膵病変が高度に進行しない時点, すなわち手術によ る效果が確実に期待できる時点で手術すべきであると考 えている.

\section{おわりに}

教室例94例の手術成績を検討した，疼痛に対する効果 は約 $90 \%$ にられ，大部分の症例では社会復帰が可能で あったが，膵内外分泌機能が改善されるものは少ないと の結果が得られた. 慢性膵炎は元来良性疾患であり内科 的治療が主体となるべきものであろらが，症例によって は手術を必要とし，また極めて有効な場合がある，各症 例の病態を十分に把握して, 手術々式や手術の時期を決 定することが大切であるが，膵の荒廃が高度になる以前 に適切な外科的療法を行うべきである. そして生活指導 を含めた膡機能不全に対する術後の治療之厳重な follow up が大切であるう.

\section{文献}

1) Smith, R.: Progress in the surgical treatment of pancreatic disease. Am. J. Surg., 125: 143, 1973.

2) Stefanini, P., et al.: Recent advances in the management of chronic pancreatitis. Surg. Italy, 3: 19, 1973.

3) Rush, A. and Bockus, H.: Gastroenterology, ed. by Bockus, W.B. Saunders, Philadelphia \& London, p. 998, 1965.

4) Griffin, J.M. and Starkloff, G.B.: Surgery of chronic pancreatitis. Am. J. Surg., 122: 18, 1971.

5) 斉藤洋一他：慢性膵炎一外科的療法の適応，そ の時期，その予後について一. 治療, 57 (8): $87,1975$.

6) 佐藤寿雄 他：慢性（反復性）櫒炎. 外科, 40 (11) : 40, 1978.

7) 佐藤寿雄 他 : 僈性愺炎一外科側一, 臨床成人 病, $9(3): 63,1979$.
8）佐藤寿雄 他：慢性膵炎の外科的治療一とくに 手術々式の選択について一, 外科診療, 17 (5)： 18 , 昭50.

9) ReMine, W.H.: Pancreatitis, ed. by Gambill, C.V., Mosby, St. Louis, p. 235, 1973.

10) Way, L.W., et al.: Surgical treatment of chronic pancreatitis. Am. J. Surg., 127: 202, 1974.

11) Guillemin, G., et al.: Chronic relapsing pancreatitis. Surgical management including sixtythree cases of pancreaticoduoenectomy. Am. J. Surg., 122: 802, 1971.

12) Fry, W.J. and Child, C.G.: Ninety-five per cent distal pancreatectomy for chronic pancreatitis. Ann. Surg., 162: 543, 1965.

13) Frey, C.F., et al.: Pancreatectomy for chronic pancreatitis. Ann. Surg., 184: 403, 1976.

14) Braasch, J.W.: Total pancreatectomy for endstage chronic pancreatitis. Ann. Surg., 188: $317,1978$.

15) Doubilet, H. and Mulholland, J.H.: Eightyear study of pancreatitis and sphincterotomy. J.A.M.A., 160: 521, 1956.

16) Jones, S.A. and Smith, L.L.: Transduodenal sphincteroplasty for recurrent pancreatitis. A preliminary report. Ann. Surg., 136: 937, 1952.

17) Nardi, G.L.: Technique of sphincteroplasty in recurrent pancreatitis. Surg. Gynec. Obstet., 110: 639, 1960.

18) DuVal, M.K. and Enqinst, K.F.: The surgical treatment of chronic pancreatitis by pancreaticojejunostomy: An-8-year reappraisal. Surgery, 50: 965, 1961.

19) Puestow, C.B. and Gillesby, W.J.: Retrograde surgical drainage of pancreas for chronic relapsing pancreatitis. Arch. Surg., 76: 898, 1958.

20) Thal, A.P.: A technique for drainage of the obstructed pancreatic duct. Surgery, 51: 313 , 1962.

21) Partington, P.F. and Rochelle, R.E.: Modified procedure for retrograde drainage of the pancreatic duct. Ann. Surg., 152: 1037, 1960.

22) White, T.T.: Pancreatitis. Edward Arnold Ltd., London, p. 169, 1966.

23) Jordan, G.L., et al.: Current status of pancreatojejunostomy in the management of chronic pancreatitis. Am. J. Surg., 133: 46, 1977.

24) Arnesjö, B., et al.: Pancreatico jejunostomy in chronic pancreatitis. An appraisal of 29 cases. Acta Chir. Scand., 141: 139, 1975.

25) White, T.T. and Keith, R.G.: Long term 
follow-up study of fifty patients with pancreaticojejunostomy. Surg. Gynec. Obstet., 136: 353, 1973.

26) Leger, L., et al.: Five to twenty year followup after surgery for chronic pancreatitis in $\mathbf{1 4 8}$ patients. Ann. Surg., 180: 185, 1974.

27) 羽生富士夫他 : 脺腸管吻合, 勝管空腈側々吻合 の適応と術式. 内科 Mook, No. $7:$ p. 127, 金原 出版, 東京, 1979.

28) Carnevali, J.F., et al.: An experimental study of side-to-side pancreatico jejunostomy atter ductal obstruction. Arch. Surg., 80: 774,
1960.

29) Stefanini, P., et al.: Surgical treatment of chronic pancreatitis. Am. J. Surg., 124: 28, 1972.

30) Warren, K.W. and Mountain, J.C.: Comprehensive management of chronic relapsing pancreatitis. Surg. Clin. N. Amer., 51: 693, 1971.

31) White, T.T.: Personal communication.

32) Anderson, M.C.: Surgical approach to pancreatic inflammatory disease. Arch. Surg., 107: $340,1973$. 